\title{
Assessment of Heavy Metals in Waterleaf from Various Sources in Ota, Nigeria
}

\author{
BABAYEMI, JO; OLAFIMIHAN, OH; NWUDE, DO
}

\author{
Department of Chemical Sciences, Bells University of Technology, Ota, Nigeria \\ Corresponding Author: E-mail: babayemola@yahoo.co.uk \\ Phone: $\quad+2348060709930$
}

\begin{abstract}
This study assessed the levels of heavy metals present in waterleaf (Talinum triangulare) from various sources in Ota, Ogun State. Eighty (80) samples of waterleaf were obtained from 5 domestic (non-hazardous) dumpsites, 5 non-dumpsites, 5 markets and 5 streets in Ota. The non-dumpsites were locations in industrial areas. Also, over 500 questionnaires were randomly administered to residents in Ota to assess the extent of consumption of waterleaf. Standard method was followed for sample treatment, digestion, and analysis of selected heavy metals: lead $(\mathrm{Pb})$, cadmium $(\mathrm{Cd})$, chromium $(\mathrm{Cr})$, nickel $(\mathrm{Ni})$ and cobalt $(\mathrm{Co})$ using Atomic Absorption Spectrometer. The results showed that in waterleaf from domestic dumpsites the concentration $(\mathrm{mg} / \mathrm{kg})$ of heavy metals were: $\mathrm{Pb}(14.50-20.10)$, $\mathrm{Cd}$ (0.05-0.60), $\mathrm{Cr}$ (0.19-2.48), $\mathrm{Ni}$ (2.75-7.30) and Co (3.40-6.05); from non-dumpsites: $\mathrm{Pb}$ (12.20-24.45), Cd (ND$0.60), \mathrm{Cr}$ (ND-2.79), Ni (ND-24.00), Co (3.75-5.75); from markets: Pb (0.35-3.85), Cd (ND), Cr (ND-7.11), Ni (ND5.10), $\mathrm{Co}$ (1.05-2.45); and from streets: $\mathrm{Pb}$ (ND-5.00), Cd (ND), Cr (ND), Ni (3.50-7.25), Co (1.50-2.50). Generally, all the heavy metals were highest in waterleaf from domestic dumpsites and non-dumpsites. There were 502 respondents to the questionnaire; of which $82 \%$ consumed waterleaf. Out of those who consumed waterleaf, $41 \%$ consumed it daily, $32 \%$ at least once in a week, and $19 \%$ at least once in two weeks. It may be concluded that there is the high tendency of exposure to heavy metals by those who consume waterleaf in the studied locations since the levels in waterleaf from all sources studied generally exceeded the FAO/WHO limits.@ JASEM
\end{abstract}

https://dx.doi.org/10.4314/jasem.v21i6.29

Keywords: Waterleaf, Talinum triangulare, vegetable, heavy metals, pollution, Ota

Waterleaf (Talinum triangulare) is one of the most common leafy vegetables in Nigeria. It is available almost throughout the year, even during the dry seasons, because of its ability to survive drought. It is a perennial herbaceous plant widely grown and consumed as a vegetable (Wilberforce, 2016). Studies have shown that waterleaf contains important nutrients and phytochemicals such as flavonoids and polyphenols, crude protein, lipids, essential oils, cardiac glycosides, omega -3-fatty acids, minerals, soluble fibres and vitamins (Swarnaj and Ravindhran, 2013). The availability and nutritional composition make it one of the most sought vegetables. However, sources of this vegetable, particularly in Ota, need assessment, considering the current scope of pollution in Nigerian cities (Olujimi et al., 2015; Ogundele et al., 2017).

Ota is a traditional city with a good number of industries of various categories, markets, and trades. These anthropogenic activities usually result in pollution, especially in developing countries where low-end waste management is the common practice (Babayemi and Dauda, 2009). Large amounts of wastes are generated and dumped daily (Minh et al., 2006; Babayemi et al., 2017). There is a serious environmental concern, considering that a larger fraction of the wastes is hazardous in nature (Babayemi et al., 2016). One category of hazardous substances being constantly monitored in the environment globally are toxic heavy metals like $\mathrm{Pb}$, $\mathrm{Cd}$, and $\mathrm{Cr}$.
The adverse human health effects of these toxic elements have been documented. Lead may cause birth defects, abnormality in behavior and learning problems in children, decreased kidney function, a reproductive disorder, cardiovascular problems, etc (Mudipalli, 2007; Wang et al., 2009; Skerfving et al., 2015). Human health effects of cadmium include genetic disorders, cancer, impairment of renal function, bronchiolitis, a decrease in hemoglobin level, etc (Cabral et al., 2015; Cartularo et al., 2015; Zang, 2016). Cadmium may cause nasal irritations, cancer, bronchitis and ulcerations of the septum, decreased pulmonary function, etc (Shanker and Venkateswarlu, 2011; Babayemi et al., 2016). These toxic elements find their way into the environment usually as a result of pollution arising from human activities, and consequently, contaminate the different environmental media on which human life depends.

Adverse effects of pollution include contamination of soil, water, air and food items (Babayemi et al., 2016; Babayemi, 2016). Food items available from various sources in a highly industrialised city like Ota may, therefore, need assessment. Other items like drinking water (Kayode et al., 2011), meat (Nwude et al., 2011), foods and drinks (Iweala et al., 2014) have been assessed. Information is scanty on levels of heavy metals in leafy vegetables available in this city, particularly in reference to sources.

Picking of vegetables like waterleaf growing naturally on non-agricultural land or sourcing it from 
the contaminated environment may pre-dispose humans to toxic pollutants. In addition to the fact that waterleaf propagates prolifically, it has extensively produced adventitious roots which have the potential to absorb toxic substances from aqueous media (Kumar et al., 2012).

The objectives of the study were to assess the extent of consumption of waterleaf in Ota using questionnaire; and to determine the concentrations of lead $(\mathrm{Pb})$, cadmium $(\mathrm{Cd})$, chromium $(\mathrm{Cr})$, nickel $(\mathrm{Ni})$ and cobalt $(\mathrm{Co})$ in waterleaf obtained from various sources in Ota.

\section{MATERIALS AND METHOD}

Sampling: The sources of waterleaf (Talinum triangulare) were selected in Ota, Ogun State with consideration of where people were likely to pick them for consumption. The dumpsites selected (Table 1) were the non-hazardous or domestic dumpsites where common refuse and household wastes were dumped. The non-dumpsites were the different locations or piece of land where waterleaf was found growing naturally. Five (5) markets and 5 different streets/communities were also selected where waterleaf may be purchased.

Domestic dumpsite (DDS) 1 was located in Bells University of Technology; DDS 2 and DDS 3 were located around Canaanland, Ota; DDS 4 and DDS 5 along Idikoro road. Market (MKT) 1 was Sango market; MKT 2, Oju-ore market; MKT 3, Iyana-Iyesi market; MKT 4, Iyana-joju (express) market; and MKT 5, Tollgate market. Non-dumpsite (NDS) 1 was a bushy piece of land located along Idiroko road, close to Nestle distribution center, Ota; NDS 2 and NDS 3 were locations within Ogun State Industrial Estate; NDS 4 was car park $G$ in the living faith church (Canaanland); NDS 5 was a bushy plane ground in Bells University of Technology. Street (STR) 1 was located along Bells drive, opposite Grand Bank Link hotel. Street 2 was Oke Ede, along Oju-ore before, Tollgate. Street 3 was Abebi street along old Ota road. Street 4 was Adeyanju street, along Obasanjo farm road. Street 5 was Ifelodun street along Iyana-joju road.

Sample treatment and analysis: The samples were washed with distilled/de-ionized water in order to remove dirt and impurities and then air-dried for about four weeks to remove enough amount of moisture; after which they were dried to constant weight at $105^{\circ} \mathrm{C}$ in the oven. The dried samples were pulverized using an electric blender.
Following a standard method described by Miroslav and Vladimir (1998), $2 \mathrm{~g}$ of pulverized sample was weighed into an acid washed, dried crucible; and completely ashed in a muffle furnace at $500{ }^{\circ} \mathrm{C}$ for 6 hours. The ashed sample was then dissolved in $5 \mathrm{ml}$ of $6 \mathrm{M}$ Nitric acid and then filtered. The filtrate was quantitatively transferred into a $50 \mathrm{ml}$ standard flask and made up to mark with distilled/de-ionized water. All the glassware used was acid washed and dried in the oven to avoid contamination of samples.

The quantitative determination of the heavy metals, namely, lead $(\mathrm{Pb})$, nickel $(\mathrm{Ni})$, cadmium $(\mathrm{Cd})$, cobalt (Co) and chromium (Cr) were carried out using Atomic Absorption Spectrometer at the central research laboratory, University of Ibadan. Each sample was analysed in duplicate and the mean was recorded. Analysis of blank was also carried out and corrected in the sample.

Survey of consumption of waterleaf in Ota: Over 500 copies of the questionnaire were randomly administered to determine the extent of consumption of waterleaf in Ota.

\section{RESULTS AND DISCUSSION}

Domestic Dumpsites (DDS): The mean concentrations of heavy metals in waterleaf from domestic dumpsites are shown in Table 2.

The concentrations in waterleaf from DDS 1 ranged from $0.19 \pm 0.25 \mathrm{mg} / \mathrm{kg}(\mathrm{Cr})$ to $14.95 \pm 1.51 \mathrm{mg} / \mathrm{kg}(\mathrm{Pb})$; DDS $2,0.05 \pm 0.11 \mathrm{mg} / \mathrm{kg}(\mathrm{Cd})$ to $14.50 \pm 2.44 \mathrm{mg} / \mathrm{kg}$ $(\mathrm{Pb})$; DDS 3, $0.25 \pm 0.43 \mathrm{mg} / \mathrm{kg}(\mathrm{Cd})$ to $15.80 \pm 3.86$ $\mathrm{mg} / \mathrm{kg}(\mathrm{Pb}) ;$ DDS 4, $0.25 \pm 0.43 \mathrm{mg} / \mathrm{kg}(\mathrm{Cd})$ to $20.10 \pm 1.19 \mathrm{mg} / \mathrm{kg}(\mathrm{Pb})$; DDS 5, $0.60 \pm 0.63 \mathrm{mg} / \mathrm{kg}$ (Cd) to $18.90 \pm 2.63 \mathrm{mg} / \mathrm{kg}(\mathrm{Pb})$.

For some supposed dietary and economic advantages, waste dump sites in some parts of Nigeria (Musa and Ifatimehin, 2013) and some other African countries (Odai et al., 2008; Kihampa et al., 2011) have been converted to agricultural sites particularly for the cultivation of vegetables.

Vegetables seem to thrive better on a piece of land with sufficient humus or decomposing organic materials. However, significant contamination of vegetables on such land may still occur.

Since the indiscriminate burning of solid wastes is a common practice in the country (Babayemi et al., 2016, 2017), toxic elements may be released into the soil and consequently taken up by plants. This may be the cause of such high level of $\mathrm{Pb}$ detected in all the domestic dumpsites studied. 


\begin{tabular}{llll} 
Table 1: Sampling design & & \\
\hline Category & Number of sites & $\begin{array}{l}\text { Number of sampling } \\
\text { points from each site }\end{array}$ & Total samples \\
& & 5 & 25 \\
\hline Domestic dumpsites (DDS) & 5 & 5 & 25 \\
Non-dumpsites (NDS) & 5 & 5 & 25 \\
Markets (MKT) & 5 & 1 & 5 \\
Streets (STR) & 5 & & 80 \\
Total & 20 & & \\
\hline
\end{tabular}

\begin{tabular}{lllllll}
\multicolumn{6}{l}{ Table 2: Concentrations (mg/kg) of heavy metals in waterleaf from domestic dumpsite sources in Ota } \\
\hline Heavy metal & $\mathrm{N}$ & DDS 1 & DDS 2 & DDS 3 & DDS 4 & DDS 5 \\
\hline $\mathrm{Ni}$ & 5 & $7.30 \pm 1.58$ & $4.45 \pm 2.38$ & $2.75 \pm 1.88$ & $7.00 \pm 3.05$ & $5.50 \pm 1.22$ \\
$\mathrm{Co}$ & 5 & $3.40 \pm 0.29$ & $4.10 \pm 0.99$ & $4.00 \pm 0.31$ & $5.95 \pm 0.11$ & $6.05 \pm 0.76$ \\
$\mathrm{Cd}$ & 5 & $0.50 \pm 0.53$ & $0.05 \pm 0.11$ & $0.25 \pm 0.43$ & $0.25 \pm 0.43$ & $0.60 \pm 0.63$ \\
$\mathrm{~Pb}$ & 5 & $14.95 \pm 1.51$ & $14.50 \pm 2.44$ & $15.80 \pm 3.86$ & $20.10 \pm 1.19$ & $18.90 \pm 2.63$ \\
$\mathrm{Cr}$ & 5 & $0.19 \pm 0.25$ & $0.19 \pm 0.41$ & $0.95 \pm 1.01$ & $2.16 \pm 0.76$ & $2.48 \pm 2.21$
\end{tabular}

\begin{tabular}{|c|c|c|c|c|c|c|}
\hline \multicolumn{7}{|c|}{ DPS = Dumpsite; $\mathrm{N}=$ number of samples } \\
\hline $\begin{array}{l}\text { Heavy } \\
\text { metal }\end{array}$ & $\mathrm{N}$ & NDS 1 & NDS 2 & NDS 3 & NDS 4 & NDS 5 \\
\hline $\mathrm{Ni}$ & 5 & $\begin{array}{l}24.00 \pm 26.5 \\
4\end{array}$ & $9.30 \pm 8.67$ & $15.85 \pm 5.64$ & $2.60 \pm 1.74$ & ND \\
\hline Co & 5 & $4.60 \pm 1.91$ & $5.75 \pm 3.98$ & $5.18 \pm 1.31$ & $3.75 \pm 0.71$ & $4.55 \pm 0.65$ \\
\hline $\mathrm{Cd}$ & 5 & $0.50 \pm 0.68$ & $0.50 \pm 0.50$ & $0.60 \pm 0.72$ & ND & $0.45 \pm 0.87$ \\
\hline $\mathrm{Pb}$ & 5 & $21.70 \pm 5.50$ & $\begin{array}{l}22.15 \pm 11.6 \\
1\end{array}$ & $24.45 \pm 5.83$ & $15.05 \pm 3.64$ & $12.20 \pm 1.69$ \\
\hline $\mathrm{Cr}$ & 5 & $0.72 \pm 1.61$ & $0.10 \pm 0.22$ & ND & $2.79 \pm 1.50$ & $2.34 \pm 1.38$ \\
\hline
\end{tabular}

\begin{tabular}{lllllll}
\multicolumn{5}{l}{ Table 4: Concentrations $(\mathrm{mg} / \mathrm{kg})$ of heavy metals in waterleaf from market sources in Ota } \\
\hline $\mathrm{Heavy}$ metal & $\mathrm{N}$ & $\mathrm{MKT}$ & MKT 2 & MKT 3 & MKT 4 & MKT 5 \\
\hline $\mathrm{Ni}$ & 5 & $\mathrm{ND}$ & $0.95 \pm 2.12$ & $4.00 \pm 1.36$ & $2.80 \pm 1.92$ & $5.10 \pm 0.38$ \\
$\mathrm{Co}$ & 5 & $1.05 \pm 1.07$ & $1.70 \pm 0.84$ & $2.00 \pm 0.56$ & $1.95 \pm 0.67$ & $2.45 \pm 0.41$ \\
$\mathrm{Cd}$ & 5 & $\mathrm{ND}$ & $\mathrm{ND}$ & $\mathrm{ND}$ & $\mathrm{ND}$ & $\mathrm{ND}$ \\
$\mathrm{Pb}$ & 5 & $3.85 \pm 1.79$ & $2.35 \pm 2.32$ & $0.35 \pm 0.65$ & $1.90 \pm 2.75$ & $2.70 \pm 0.48$ \\
$\mathrm{Cr}$ & 5 & $\mathbf{7 . 1 1} \pm \mathbf{0 . 5 9}$ & $\mathrm{ND}$ & $\mathrm{ND}$ & $0.64 \pm 0.28$ & ND
\end{tabular}

MKT $=$ Market

\begin{tabular}{llllll}
\multicolumn{5}{l}{ Table 5: Concentrations $(\mathrm{mg} / \mathrm{kg})$} & of heavy metals in waterleaf from street sources in Ota \\
\hline Heavy metal & STR 1 & STR 2 & STR 3 & STR 4 & STR 5 \\
\hline $\mathrm{Ni}$ & $5.5 \pm 0.13$ & $7.25 \pm 0.13$ & $4.25 \pm 0.58$ & $5.5 \pm 2.48$ & $3.5 \pm 0.03$ \\
$\mathrm{Co}$ & $1.75 \pm 0.18$ & $2.25 \pm 0.20$ & $1.5 \pm 0.65$ & $2.5 \pm 0.25$ & $1.75 \pm 0.25$ \\
$\mathrm{Cd}$ & $\mathrm{ND}$ & $\mathrm{ND}$ & $\mathrm{ND}$ & $\mathrm{ND}$ & $\mathrm{ND}$ \\
$\mathrm{Pb}$ & $1 \pm 1.05$ & $1.00 \pm 0.00$ & $1.50 \pm 0.95$ & $5.00 \pm 2.83$ & $\mathrm{ND}$ \\
$\mathrm{Cr}$ & $\mathrm{ND}$ & $\mathrm{ND}$ & $\mathrm{ND}$ & $\mathrm{ND}$ & $\mathrm{ND}$
\end{tabular}

$\mathrm{STR}=$ street

Several studies have shown that waterleaf has the potential to accumulate heavy metals from dumpsites (Rajkumar et al., 2009; Uwah et al., 2009). Generally high level of pollution in Ota, being an industrial city, may also contribute to this. However, the levels were slightly lower compared to what is actually obtainable in a typical municipal dumpsite in Nigeria. For instance, Eze (2014) reported $\mathrm{Pb}$ level of 20.26 to $25.10 \mathrm{mg} / \mathrm{kg}$ in waterleaf around municipal dumpsite in Gombe, Nigeria; and Ebong et al. (2008) reported a level of 43.28 $\mathrm{mg} / \mathrm{kg}$ for municipal dumpsite in Uyo. On the other hand, it may be inferred that the levels obtained in this study were high compared to what may be expected for the unpolluted environment. Eze (2014) reported a level of $1.50-2.42 \mathrm{mg} / \mathrm{kg}$ for a relatively unpolluted nondumpsite area.

The FAO/WHO (2011) standard for $\mathrm{Pb}$ in the vegetable is 0.3 $\mathrm{mg} / \mathrm{kg}$. Consumption of waterleaf (or vegetables generally) grown on a domestic dumpsite in Ota may constitute severe health hazards. The domestic dumpsites in Ota may therefore not be categorized as non-hazardous. This informs that the ancient or traditional practice of harvesting vegetables from domestic dumpsite for human consumption is not safe in the modern times experiencing detrimental levels of toxic pollutants in almost all environmental media. The levels of $\mathrm{Cr}$ were within the $\mathrm{FAO} / \mathrm{WHO}$ (2001) limit of $2.30 \mathrm{mg} / \mathrm{kg}$ in leafy vegetables, while those of $\mathrm{Cd}$ were slightly higher than the limit $(0.2$ $\mathrm{mg} / \mathrm{kg}$ ).

Non-Dumpsites (NDS): The mean concentrations of heavy metals in waterleaf from non-dumpsites are shown in Table 3. The concentrations in waterleaf from NDS 1 ranged from $0.50 \pm 0.68$ $\mathrm{mg} / \mathrm{kg}$ (Cd) to $24.00 \pm 26.54 \mathrm{mg} / \mathrm{kg}$ (Ni); NDS 2, 0.10 $\pm 0.22 \mathrm{mg} / \mathrm{kg}(\mathrm{Cr})$ to $22.15 \pm 11.61 \mathrm{mg} / \mathrm{kg}(\mathrm{Pb})$; NDS 3 , $\mathrm{ND}(\mathrm{Cr})$ to $24.45 \pm 5.83 \mathrm{mg} / \mathrm{kg}(\mathrm{Pb})$; NDS 4, ND (Cd) to $15.05 \pm 3.64$ $\mathrm{mg} / \mathrm{kg}(\mathrm{Pb})$; NDS 5, ND (Ni) to $12.20 \pm 1.69 \mathrm{mg} / \mathrm{kg}(\mathrm{Pb})$.

Theoretically, it should be expected that the concentrations of the heavy metals in waterleaf from dumpsites would be far higher than those from non-dumpsites. But the reverse was the case in this study. It has been explained that the dumpsites were domestic ones. The levels of heavy metals may not be comparable to those obtainable on hazardous dump sites. 
Furthermore, the location of the non-dumpsites may suggest such high levels. Non-dumpsite (NDS) 1 was a bushy piece of land located along Idiroko road, close to industries, and with parking and servicing of heavy trucks. Non-dumpsites (NDS) 2 and 3 were locations within Ogun State Industrial Estate, Ota. The high level of heavy metals might be a reflection of severe pollution of soil from the release or emission of pollutants from industries and consequently taken up by the plants growing on the soil (Al-Rashdi and Sulaiman, 2013). Kailas (2013) also recorded high levels of heavy metals for various leafy vegetables grown in industrial areas of Nashik city, India, compared with those away from industrial and city areas. Non-dumpsite (NDS) 4 was car park $\mathrm{G}$ in the living faith church (Canaanland). Being a car park, the release of fluids and emission of gaseous particulates might have contaminated the soil and hence the plants growing on it. Levels from nondumpsite (NDS) 5 were the lowest; the location was a bushy plane ground in Bells University of Technology. However, the concentration of heavy metals in waterleaf from this source still far exceeded the FAO/WHO limit. One observation again was that industries were located close to the university. While on one hand, these high levels depict the extent of contamination of soil in the study locations; on the other hand, it signals risks to those picking vegetables from non-agricultural land in Ota.

Markets (MKT) and streets (STR): The mean concentrations of heavy metals in waterleaf from markets are shown in Table 4. The concentrations in MKT 1 ranged from $\mathrm{ND}(\mathrm{Ni}$ and $\mathrm{Cd})$ to $7.11 \pm 0.59$ $\mathrm{mg} / \mathrm{kg}(\mathrm{Cr})$; MKT 2, ND (Cd and $\mathrm{Cr}$ ) to 2.35 \pm 2.32 $\mathrm{mg} / \mathrm{kg}(\mathrm{Pb})$; MKT 3, ND (Cd and $\mathrm{Cr}$ ) to $4.00 \pm 1.36$ $\mathrm{mg} / \mathrm{kg}(\mathrm{Ni}) ; \mathrm{MKT} 4$, ND (Cd) to $2.80 \pm 1.92 \mathrm{mg} / \mathrm{kg}$ (Ni); MKT 5, ND (Cr and Cd) to $5.10 \pm 0.38 \mathrm{mg} / \mathrm{kg}$ (Ni).

Levels of heavy metals in waterleaf from this source were far lower compared to those from domestic dumpsites and non-dumpsites. Cadmium was not detected at all; while Cr was detected only in samples from MKT 1 and MKT 4. Though generally low, levels of $\mathrm{Pb}$ were still higher than the FAO/WHO limit, except in samples from MKT 3.

The mean concentrations of heavy metals in waterleaf from street sources are shown in Table 5. The concentrations in waterleaf from STR 1 ranged from ND (Cr and $\mathrm{Cd}$ ) to $5.50 \pm 0.13 \mathrm{mg} / \mathrm{kg}(\mathrm{Ni}) ; \mathrm{STR}$ 2, ND (Cd and $\mathrm{Cr}$ ) to $7.25 \pm 0.13 \mathrm{mg} / \mathrm{kg}(\mathrm{Ni})$; STR 3, $\mathrm{ND}(\mathrm{Cd}$ and $\mathrm{Cr}$ ) to $4.25 \pm 0.58 \mathrm{mg} / \mathrm{kg}(\mathrm{Ni})$; STR 4, ND $(\mathrm{Cd}$ and $\mathrm{Cr}$ ) to $5.50 \pm 2.48 \mathrm{mg} / \mathrm{kg}(\mathrm{Ni})$; STR 5, ND
$(\mathrm{Cr}, \mathrm{Cd}$ and $\mathrm{Pb}$ ) to $3.50 \pm 0.03 \mathrm{mg} / \mathrm{kg}(\mathrm{Ni})$. In waterleaf from street sources, the levels of heavy metals were similar to those from market sources. Cadmium and $\mathrm{Cr}$ were not detected at all. Levels of $\mathrm{Pb}$ exceeded the FAO/WHO limit, except in samples from STR 5 where it was not detected.

The reasons for these lower levels of heavy metals in samples from markets and streets compared to domestic dumpsites and non-dumpsites might be that the waterleaf being sold in the market and streets were from agricultural lands relatively far from the city or industrial areas. These values were comparable to those in the range of $0.00 \pm 0.091$ to $3.99 \pm 0.173 \mathrm{mg} / \mathrm{kg}$ reported by Afolami et al. (2010) for Mushin market and Oba farm in Lagos. Similar levels of $0.52 \pm 0.01$ to $3.42 \pm 0.04 \mathrm{mg} / \mathrm{kg}(\mathrm{Pb})$ and $0.38 \pm 0.05$ to $1.82 \pm 0.10 \mathrm{mg} / \mathrm{kg}(\mathrm{Ni})$ were reported by Dan et al. (2013) for waterleaf sourced from markets in Akwa Ibom State; and levels of 0.05 to $0.20 \mathrm{mg} / \mathrm{kg}(\mathrm{Cd}), 0.34$ to $5.44 \mathrm{mg} / \mathrm{kg}(\mathrm{Pb}), 0.25$ to $1.51 \mathrm{mg} / \mathrm{kg}(\mathrm{Cr})$ reported by Adedokun et al. (2016) for four markets in Lagos. This may then inform that it is safer to source waterleaf (and vegetables generally) from the market than picking them from just anywhere they grow, especially in Ota.

Survey of consumption of waterleaf in Ota: There were 502 respondents to the questionnaires. The results of the survey showed that $82 \%$ of the respondent consumed water leaf while $18 \%$ did not. Figure 2 shows the frequency of consumption of waterleaf:, $41 \%$ of the respondent consumed it daily, $32 \%$ of the respondent consumed it once in a week, $19 \%$ once in two weeks; $4 \%$ once in a month; $2 \%$ once in three months, $1 \%$ once in six months and $1 \%$ once in a year. Also, the response showed that $80 \%$ of the respondents prepared and consumed it at home while $20 \%$ consumed it at the cafeteria.

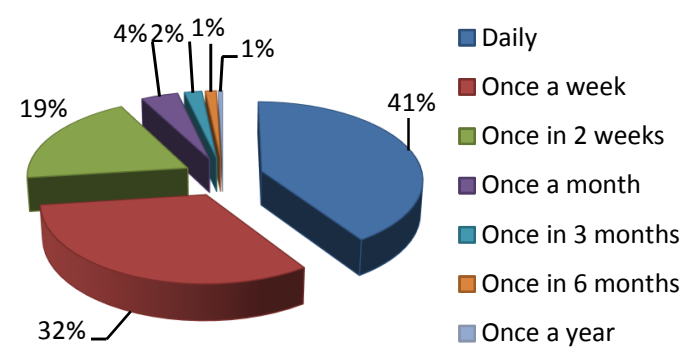

Fig 2: Frequency of consumption of waterleaf 
Furthermore, it was discovered that $80 \%$ bought the waterleaf from the market while $20 \%$ picked it anywhere it grew.

Since this study had already revealed that the levels of heavy metals in waterleaf sourced from markets and streets were lower compared to those from dumpsites and non-dumpsites in Ota, it may then be inferred that about $20 \%$ of the respondents (and by extension, of the population in Ota) who consumed waterleaf sourced from dumpsites and non-dumpsites in this city may be at the risk of exposure to heavy metals.

Conclusion: It may be concluded that there is the high tendency of exposure to heavy metals by those who consume waterleaf in Ota since the levels in waterleaf from all sources studied generally exceeded the FAO/WHO limits. However, it seems safer to purchase waterleaf from the market for human consumption than picking it from wherever it grows, be it dumpsites or non-dumpsites. It may be guessed that the ones sold on the market were from farmlands remote from the city since the concentrations of heavy metals in waterleaf from this source were the lowest. Finally, high levels of heavy metals in waterleaf from Ota exceeding FAO/WHO permissible limits call for concern and thorough environmental monitoring in this highly industrialized city.

Acknowledgements:The authors acknowledge Bells University of Technology, Ota, for providing a conducive environment to carry out this study.

\section{REFERENCES}

Adedokun, AH; Njoku, KL; Akinola, MO; Adesuyi, AA; Jolaoso, AO (2016). Potential Human Health Risk Assessment of Heavy Metals Intake via Consumption of some Leafy Vegetables obtained from Four Market in Lagos Metropolis, Nigeria. J. Appl. Sci. Environ. Manage. 20 (3): 530-539.

Afolami, I; Anyakora, C; Ebuehi, O; Bolawa, O (2010). Lead levels in some edible vegetables in Lagos, Nigeria. Scientific Research and Essays 5 (8): 813818.

Al-Rashdi, TT; Sulaiman, H (2013). Bioconcentration of Heavy Metals in Alfalfa (Medicago sativa) from Farm Soils around Sohar Industrial Area in Oman. APCBEE Procedia 5: 271 - 278.

Babayemi, JO (2016). Overview of Levels of Organochlorine Pesticides in Surface Water and Food Items in Nigeria. Journal of Environment and Earth Science 6 (8): 77-86.
Babayemi, JO; Dauda, KT (2009). Evaluation of solid waste generation, categories and disposal options in developing countries: a case study of Nigeria. Journal of Applied Sciences and Environmental Management 13(3): 83-88. ISSN: 1119-8362.

Babayemi, JO; Ogundiran, MB; Osibanjo O (2016). Overview of environmental hazards and health effects of pollution in developing countries: a case of Nigeria. Environmental Quality Management 26 (1): 51-71.

Babayemi, JO; Ogundiran, MB; Osibanjo, O (2017). Current levels and management of solid wastes in Nigeria. Environmental Quality Management (in press).

Cabral, M; Toure, A; Garçon, G; Diop, C; Bouhsina, S; Dewaele, D; Cazier, F; Courcot, D; Tall-Dia, A; Shirali, P; Diouf, A; Fall, M; Verdin, A (2015). Effects of environmental cadmium and lead exposure on adults neighboring a discharge: Evidences of adverse health effects. Environmental Pollution 206: 247-255.

Cartularo, L; Laulicht, F; Sun, H; Kluz, T; Freedman, JH; Costa, M (2015). Gene expression and pathway analysis of human hepatocellular carcinoma cells treated with cadmium. Toxicology and Applied Pharmacology 288(3): 399-408.

Codex Alimentarius Commission (FAO/WHO) (2001). Food additives and contaminants-joint FAO/WHO Food standards programme. ALINORM 01/12A: p.1289.

Dan, EU; Udo, UE; Ituen, EB (2013). Comparative Assessment of Proximate and Heavy Metal Composition in Some Selected Edible Vegetable Leaves Sourced from Three Major Markets in Akwa Ibom State, Southern Nigeria. Australian Journal of Basic and Applied Sciences 7(8): 676-682, 2013.

Ebong, GA; Akpan, MM; Mkpenie, VN (2008). Heavy Metal Contents of Municipal and Rural Dumpsite Soils and Rate of Accumulation by Carica papaya and Talinum triangulare in Uyo, Nigeria. E-Journal of Chemistry 5 (2): 281-290.

Eze, MO (2014). Evaluation of Heavy Metal Accumulation in talinum triangulare grown around Municipal solid waste dumpsites in Nigeria. Bulletin of Environment, Pharmacology and Life Sciences 4 (1): 92-100.

FAO/WHO (2011). Joint FAO/WHO Food standards programme . Codex Committee on contaminants in foods. Fifth Session. The Hague, The Netherlands, 21 - 25 March 2011, CF/5 INF/1, Working document for information and use in discussions related to contaminants and toxins in the GSCTFF.

Iweala, EEJ; Olugbuyiro, JAO; Durodola, BM; FubaraManuel, DR; Okoli, AO (2014). Metal Contamination 
Of Foods and Drinks Consumed in Ota, Nigeria. Research Journal of Environmental Toxicology 8 (2): 92-97.

Kailas, RL (2013). Assessment of Heavy Metal Contamination in Vegetables Grown in and Around Nashik City, Maharashtra State, India. IOSR Journal of Applied Chemistry 5 (3): 09-14.

Kayode, AAA; Babayemi, JO; Abam, EO; Kayode, OT (2011). Occurrence and health implications of high concentrations of Cadmium and Arsenic in drinking water sources in selected towns of Ogun State, South West, Nigeria. Journal of Toxicology and Environmental Health Sciences 3(15): 385-391.

Kihampa, C; Mwegoha, WJS; Shemdoe, RS (2011). Heavy metals concentrations in vegetables grown in the vicinity of the closed dumpsite. International Journal of Environmental Sciences 2 (2): 889-895.

Kumar, A; Prasad, MNV; Sytar, O (2012). Lead toxicity, defense strategies and associated indicative biomarkers in Talinum triangulare grown hydroponically. Chemosphere 89: 1056-1065.

Miroslav, R; Vladimir, NB (1998). Plant analysis. Practical Environmental Analysis. Pp. 379 - 397.

Mudipalli, A (2007). Lead hepatotoxicity \& potential health effects. Indian Journal of Medical Research 126 (6): 518-527.

Musa, SD; Ifatimehin, OO (2013). Human Health Implications of Waste Dump Cultivated Vegetables in Anyigba, Kogi State, Nigeria. Research Journal of Environmental and Earth Sciences 5 (12): 710-713

Nwude, DO; Babayemi, JO; Abhulimen, IO (2011). Metal quantification in cattle: a case of cattle at slaughter at Ota abattoir, Nigeria. Journal of Toxicology and Environmental Health Sciences 3(9): 271-274.

Odai, SN; Mensah, E; Sipitey, D; Ryo, S; Awuah, E (2008). Heavy Metals Uptake by Vegetables Cultivated on Urban Waste Dumpsites: Case Study of Kumasi, Ghana. Research Journal of Environmental Toxicology 2: 92-99.

Ogundele, LT; Owoade, OK; Hopke, PK; Olise, FS (2017). Heavy metals in industrially emitted particulate matter in Ile-Ife, Nigeria. Environmental Research 156: 320325 .
Olujimi, O; Steiner, O; Goessler, W (2015). Pollution indexing and health risk assessments of trace elements in indoor dusts from classrooms, living rooms and offices in Ogun State, Nigeria. Journal of African Earth Sciences 101: 396-404.

Rajkumar, K; Sivakumar, S; Senthilkumar, P; Prabha, D; Subbhuraam, CV; Song, YC (2009). Effects of selected heavy metals $(\mathrm{Pb}, \mathrm{Cu}, \mathrm{Ni}$ and $\mathrm{Cd})$ in the aquatic medium on the restoration potential and accumulation in the stem cuttings of the terrestrial plant, Talinum triangulare Linn. Ecotoxicology 18: 952-960.

Shanker, AK; Venkateswarlu, B (2011). Chromium: Environmental pollution, health effects and mode of action. In Encyclopedia of Environmental Health 2011 (pp. 650-659). Amsterdam, The Netherlands: Elsevier. doi:10.1016/B978-0-444-52272-6.00390-1.

Skerfving, S; Löfmark, L; Lundh, T; Mikoczy, Z; Strömberg, U (2015). Late effects of low blood lead concentrations in children on school performance and cognitive functions. NeuroToxicology 49: 114-120.

Swarna, J; Ravindhran, R (2013). Pharmacognostical and phytochemical evaluation of Talinum triangulare (jacq.) willd. International Journal of Pharmacy and Pharmaceutical Sciences 5 (2): 249-256.

Uwah, EI; Ndahi, NP; Ogugbuaja, VO (2009). Study of the levels of some agricultural pollutants in soils and water leaf (Talinum triangulare) obtained in Maiduguri, Nigeria. J. Appl. Sci. Environ. Sanit. 4: 71-78.

Wang, Q; Zhao, HH; Chen, JW; Gu, KD; Zhang, YZ; Zhu, YX; Ye, LX (2009). Adverse health effects of lead exposure on children and exploration to internal lead indicator. Science of the Total Environment 407 (23): 5986-5992.

Wilberforce, JOO (2016). Phytoremediation of Metal Component of Oil Spill Site Using Common Vegetables. Middle-East Journal of Scientific Research 24 (3): 962-966.

Zang, Y (2016). Cadmium: Toxicology. In Encyclopedia of Food and Health 2016 (pp. 550-555). Amsterdam, The Netherlands: Elsevier. doi:10.1016/B978-0-12384947-2.00097-0 